\title{
General English Learners' Perceptions of English for Science and Technology: The Case of Third Year Applied Language Studies Learners, University of Constantine
}

\begin{abstract}
:
The aim of this article is to investigate third year General English learners' perceptions of English for Science and Technology. The latter is a subject introduced in the curriculum of "Licence LMD in English" to give students an idea about the basic theoretical notions of EST and to train them for reading, understanding, and writing an EST paragraph. In the Department of English, at the University of Constantine 1, a team of teachers have chosen as a teaching material a textbook which is entitled"Minimum Competence in Scientific English" to teach EST without having carried out a formal evaluation of this textbook to establish its efficacy and suitability to the intended population. This makes it even more interesting to study General English learners' perceptions towards EST as the content of the textbook presupposes having background knowledge in science and technology and this can be challenging to our learners what intrigues us to know their attitudes. To carry out a thorough evaluation of this coursebook, a questionnaire is given to eighty students chosen randomly from third year linguistics and Applied Language Studies option. The results reveal that the participants are not aware of their needs though they have positive attitudes towards EST.
\end{abstract}

Keywords: English for Science and Technology (EST), learners' perceptions, needs awareness, choice of materials

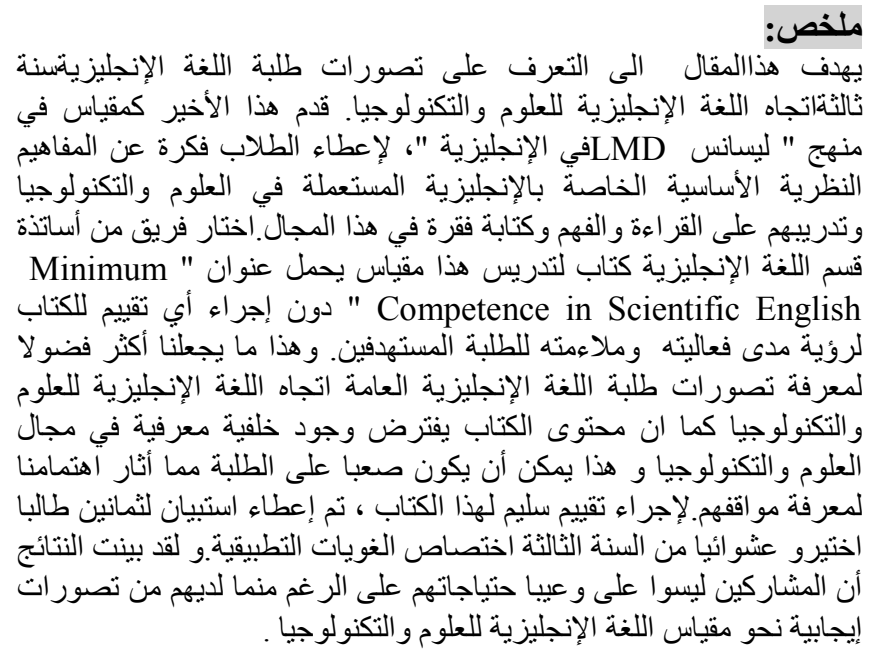

\section{DJARBOU Nesrine}

Faculty of Letters and Languages Department of Foreign Languages

University of Mentouri Constantine

\begin{abstract}
Introduction :
ESP is one of the main branches of Applied Linguistics that was first known in the 1960's and became so popular at that time as it met the needs of students and workers, especially in scientific and technical fields. Many research studies have been carried out in ESP in different fields, especially in the sciences departments.
\end{abstract}


In this article, we will try to shed some light on how EST is being taught at the department of English, as far as the learners' perceptions and attitudes are concerned, by means of a course book entitled "Minimum Competence in Scientific English". The book, which is designed for students of scientific and technological universities, institutes of technology, and schools for engineers who major in English, is chosen by a team of teachers to teach third year Applied language studies learners without really conducting a needs analysis research. This is what actually pushed us to shed light on the perceptions of language learners or General English learners towards the EST module as the content of the course requires having background knowledge in science and technology.

\section{Historical background}

English for Science and Technology (EST) is considered as a "driving force" (Flowerdew, 1990, p.328) which enables access to technology and science (Kennedy and Bolitho, 1984). EST is one of the main branches of ESP since "much of the demand for ESP come from scientists and technologists who need to learn English for a number of purposes connected with their specialism" (Ibid, p.6). EST is interested in the analysis of scientific and technical discourse in terms of language functions and grammatical notions (Trimble, 1985). Description, definition, classification, instructions, visualverbal relationship are the five rhetorical functions emphasized by Trimble (ibid), in addition to the rhetorical notions like time order, causality and result, comparison and contrast and exemplification (Wilkins, 1976). Widdowson (1979, p.45) defines EST as "not as a separate operation but as a development from an alternative realization of what has already been learnt, that is to say, of existing knowledge", i.e. the students should have knowledge in science in addition to knowledge in English. However, this is not the case with Applied Language Studies students in our department because although they have studied science and technology for two (common trunk) years, they continue not to have enough background knowledge about science. Hence, if learners deal with such functions and notions and see how they are expressed and used in scientific discourse, we believe that they will be able to cope -with greater easiness- with any piece of EST discourse they meet, or at least reduce difficulties.

Learners' perceptions and needs play a vital role in the design and implementation of any course whether in general or specific contexts (Hutchinson and Waters, 1987; Robinson, 1991; Jordan, 1997; Dudley-Evans and St. John, 1998; Iwai et al. 1999 and elsewhere; Gao 2007) as the choice of materials should be related to the learners' field of specialization (Bojovic, 2006). Previously, it was thought that needs analysis is only related to ESP courses, and the idea is still dominant for "course design plays a relatively minor part in the life of the General English teacher (where) courses (are) 
General English Learners' Perceptions of English for Science and Technology: The Case of Third Year Applied Language Studies Learners, University of Constantine

determined either by tradition, choice of textbook or ministerial decree" (Hutchinson and Waters, 1987, p.21). Thus, in most -if not all cases- learners' perceptions and attitudes continue to be neglected. With such inconvenience, our aim is to precisely adopt an analytical outlook with regard to General English learners' attitudes and perceptions towards English for Science and Technology, and to try to consider and/or reconsider how to otherwise use the coursebook to make it [truly] meet learners' needs and wants (the latter means what students need but they don't know they need).

\section{Methodology}

\subsection{Participants}

The sample of this study consists of 80 students chosen randomly from third year Linguistics and Applied Language Studies at the Department of Letters and English Language, University of Constantine 01, Algeria.

\subsection{Data Collection and Procedure}

Data were collected using a questionnaire that includes closed-ended and open-ended questions. The latter are used to examine the participants' justifications of the 'yes' or 'no' questions for the purpose of obtaining a substantial understanding of the participants' views about the EST module. Furthermore, these responses provide us with significant illustrative quotes and help us identify issues not previously anticipated.

The students answered the questionnaire during their ordinary EST class. The researcher monitored the questionnaire administration, and the respondents were given all the time they needed to answer the questionnaire.

\section{Results and Discussion}

\subsection{Baccalaureate and Access to the University}

To know about the respondents' background knowledge and ability to understand and to deal with scientific and technical subjects, we asked them about what they studied in high school. The results are given in the table below.

\begin{tabular}{|l|c|c|}
\hline \multicolumn{1}{|c|}{ Bac } & $\mathbf{N}^{\circ}$ & \% \\
\hline Letters & 58 & 72.50 \\
\hline Sciences & 21 & 26.25 \\
\hline Management and Economics & 01 & 01.25 \\
\hline Total & 80 & 100 \\
\hline
\end{tabular}

Table 1: Baccalaureate and Access to University 
Out $\mathrm{f}$ the total respondents $(\mathrm{N}=80), 72.50 \%$ come from the Lettres classes, while only $26.25 \%$ studied science in high school against $01.25 \%$ (one student) who studied Management and Economics. This shows that the majority of students do not have background knowledge in scientific and technical subjects.

\subsection{Students' overall perceptions about EST}

After having an idea about the participants background knowledge, we think it is worthy to ask them about their general attitudes towards EST. The following table summarizes the students overall perceptions.

\begin{tabular}{|c|c|c|c|c|}
\hline \multirow[t]{2}{*}{ Questions } & \multicolumn{2}{|c|}{ Yes } & \multicolumn{2}{|c|}{ no } \\
\hline & $\mathrm{N}^{\circ}$ & $\%$ & $\mathrm{~N}^{\circ}$ & $\%$ \\
\hline 1. Do you like EST module? & 61 & 76.25 & 19 & 23.75 \\
\hline $\begin{array}{l}\text { 2. Are you satisfied with what you are studying } \\
\text { in EST? }\end{array}$ & 60 & 75 & 20 & 25 \\
\hline 3. Do you enjoy the activities in your EST class? & 64 & 80 & 16 & 20 \\
\hline $\begin{array}{l}\text { 4. Are the objectives of the EST course clear } \\
\text { you? }\end{array}$ & 40 & 50 & 40 & 50 \\
\hline $\begin{array}{l}\text { 5. Do you need to write paragraphs about some } \\
\text { scientific and technical topics? }\end{array}$ & 48 & 60 & 32 & 40 \\
\hline
\end{tabular}

Table 2: The Respondents' Overall Perceptions

The results of table 2 show that $80 \%$ of the respondents say they enjoy the activities they had in class; an overwhelming majority $(76.25 \%)$ of the subjects seems to like the EST module, and almost the same number (75\%) expressed satisfaction with what they are studying in EST; against $23.75 \%$ who expressed their disliking of EST. This can be understood by the fact that in all likelihood, learners appreciated the easiness of the exercises since they didn't need much effort because the textbook focuses on learning vocabulary and fill in the gaps exercises. Yet, we think that this is not enough for language learners to know about scientific and technical English. These results prove, in fact, that learners are not aware of their needs. This can be illustrated by the fact that, as shown in table $\mathrm{N}^{\circ} 2$, there is no clear difference between the students who find the EST objectives clear (50\%) and those who find them unclear (47.50\%).

The results, as revealed in table 2 , also show that $60 \%$ of the participants think that it is important to write paragraphs about scientific and technical topics and $40 \%$ of them think it is not. This indicates that the participants are not aware of the importance of writing in empowering their knowledge of how EST discourse is structured as the language functions and 
General English Learners' Perceptions of English for Science and

Technology: The Case of Third Year Applied Language Studies Learners, University of Constantine

notions and the distribution of ideas in this type of discourse are not the same as the other ones.

\subsection{Materials, Exercises and Functions Needed by the Learners}

Always concerning the students' perceptions of EST, we asked them about the materials they need to study EST, about the exercises that help them more to learn this subject and about the language functions, they think, they need to know more about in EST. Table 3 shows the results of the students' perceptions of materials, exercises and functions needed to study EST.

Table 3: Materials, Exercises and Functions Needed

\begin{tabular}{|c|c|c|c|c|c|c|c|c|}
\hline \multicolumn{3}{|c|}{ Materials needed } & \multicolumn{3}{|c|}{ Exercises needed } & \multicolumn{3}{|c|}{ Functions needed } \\
\hline choices & $\mathrm{N}$ & $\%$ & Choices & $\begin{array}{c}\mathrm{N} \\
0\end{array}$ & $\%$ & Choices & $\begin{array}{c}\mathrm{N} \\
\mathrm{O}\end{array}$ & $\%$ \\
\hline $\begin{array}{l}\text { Handouts } \\
\text { Textbook } \\
\text { s } \\
\text { Audio- } \\
\text { visual } \\
\text { aids } \\
\text { All of } \\
\text { them }\end{array}$ & $\begin{array}{l}19 \\
19 \\
19\end{array}$ & $\begin{array}{c}23.7 \\
5 \\
23.7 \\
5 \\
23.7 \\
5\end{array}$ & $\begin{array}{l}\text { Fill in the } \\
\text { gaps } \\
\text { Reading } \\
\text { comprehensio } \\
n \\
\text { Analyzing } \\
\text { functions and } \\
\text { notions }\end{array}$ & $\begin{array}{l}40 \\
49 \\
52\end{array}$ & $\begin{array}{c}50 \\
61.2 \\
5 \\
65\end{array}$ & $\begin{array}{l}\text { Definition } \\
\text { Description } \\
\text { Classificatio } \\
\mathrm{n} \\
\text { Instructions } \\
\text { Visual- } \\
\text { verbal } \\
\text { relationship } \\
\text { All of them }\end{array}$ & $\begin{array}{l}24 \\
15 \\
11 \\
13 \\
12\end{array}$ & $\begin{array}{c}30 \\
18.7 \\
5 \\
13.7 \\
5 \\
16.2 \\
5 \\
15 \\
\\
47.5 \\
0\end{array}$ \\
\hline
\end{tabular}

The analysis of the data shows that $23.75 \%$ of the subjects prefer to use handouts in their EST courses. The same number $23.75 \%$ like using textbooks, and another time the same number $(23.75 \%)$ appreciate the use of audio-visual aids; $43.75 \%$ of the participants like to use all of the previously mentioned materials in EST. In asking the subjects about the exercises needed, of the total respondents $(\mathrm{N}=80) 65 \%$, as shown in table 3, think that reading comprehension exercises help them more in learning EST, $61.25 \%$ think that analyzing functions and notions help them more, and $50 \%$ have chosen fill in the gaps exercises. In another respect, when the respondents are asked about the functions they need to know about, $47.50 \%$ of them chose all of them, $30 \%$ chose definition, $18.75 \%$ chose description, $16.25 \%$ pick out instructions, $15 \%$ select visual-verbal relationship , $13.75 \%$ chose classification, and $05 \%$ of the subjects did not answer. Of course, as Applied Language Studies language learners, they should know about all the functions used in EST.

\subsection{Skills Developed in the EST Course}


The participants were asked also whether the exercises they are dealing with in their EST course help them develop their reading and writing skills. The results are revealed in table 4 below.

\begin{tabular}{|l|c|c|c|c|}
\hline Questions Options & \multicolumn{2}{|c|}{ Yes } & \multicolumn{2}{c|}{ no } \\
\cline { 3 - 6 } & $\mathrm{N}^{\circ}$ & $\%$ & $\mathrm{~N}^{\circ}$ & $\%$ \\
\hline Help develop the reading skill & 58 & 72.50 & 22 & 27. \\
& & & & 75 \\
\hline Help develop the writing skill & 61 & 76.25 & 19 & 23.75 \\
\hline
\end{tabular}

Table 4: Skills Developed in the EST Course

The above table shows that considerable number of students $(72.50 \%)$ think that the exercises they are dealing with in EST help them enhance their reading skill and $76.25 \%$ of them think that the exercises develop their writing skill. In the former case,the participants justified their answers by saying that when dealing with exercises in their EST class, the explanation of difficult words and their pronunciation help them enhance their reading skill. This reveals the fact that the participants are not aware at all of what may enhance their reading skill as the reasons given are not enough for developing it. In the latter case, the subjects think that acquiring new words, knowing how to spell them, and using them in their writings, help them develop their writing skill. In addition, the participants said that they are studying in EST things related to grammar, such as cause and consequence and link words, and this helps them avoid grammatical mistakes when they write. Here, we can ask ourselves if the learners will really use these things accurately in practice and without knowing how they will express their ideas, i.e. defining, classifying, comparing, etc.

\subsection{Learners' Expectations}

In the same vein, the subjects were asked about what they expect to achieve at the end of their EST course. The subjects provided different answers which are summarized in the following table.

\begin{tabular}{|l|c|l|c|}
\hline \multicolumn{1}{|c|}{ Learners' expectations } & $\mathbf{\%}$ & Learners 'expectations & $\%$ \\
\hline Learn a lot of vocabulary & $\mathbf{4 0}$ & Communicate easily with other & $\mathbf{0 1 . 2 5}$ \\
\hline $\begin{array}{l}\text { Gainknowledge about science ar } \\
\text { technology }\end{array}$ & $\mathbf{1 7 . 5 0}$ & Having good mark & $\mathbf{0 3 . 7 5}$ \\
\hline Be able to understand & $\mathbf{0 7 . 5 0}$ & Gain good level in English & $\mathbf{0 3 . 7 5}$ \\
\hline Be able to write scientific texts & $\mathbf{0 7 . 5 0}$ & Achieve nothing & $\mathbf{0 2 . 5 0}$ \\
\hline Know grammatical rules & $\mathbf{0 1 . 2 5}$ & I do not know & $\mathbf{0 2 . 5 0}$ \\
\hline No answer & $\mathbf{1 2 . 5 0}$ & & \\
\hline
\end{tabular}


Table 5: Learners' Expectations

Table 5 reveals that the participants (40\%) expect to learn a lot of vocabulary, gain knowledge about science and technology (17.50\%), and other ones did not answer at all (12.50\%). Other students expect that they will be able to understand $(07.50 \%)$ and write $(07.50 \%)$ scientific texts, know grammatical rules $(01.25 \%)$, and communicate easily with others $(01.25$ $\%)$.Other students said that they expect to have a good mark $(03.75 \%)$ and a good level in English $(03.75 \%)$. In addition, there are some students who say that they will achieve nothing $(02.50 \%)$, the rest do not know $(02.50 \%)$. In this respect, acquiring a lot of vocabulary and learning some grammatical rules is not what learners should gain from studying EST which is considered as one of the main branches in Applied Linguistics. Concerning the rest of the participants' expectations, we can simply say that dealing only with vocabulary items and fill in the gaps exercises do not enable learners to understand and write scientific texts as they do not help them communicate easily as they think.

\section{Conclusion}

The analysis of the results obtained allows understand third year Applied Language Studies students' perceptions towards English for Science and Technology. In considering the respondents' answers and justifications, it appears that students are not aware of their needs. This can be illustrated by the fact that the content of the current EST course affects negatively the students' perspectives to the point that although they are third-year students, they are satisfied with [easy] leaning vocabulary and fill-in-the gaps exercises, which is far incommensurate with what they are expected to do with the EST course! The outcomes of this shorthand data analysis may help in making teachers and course designers conduct a serious and pertinent needs analysis. The latter will permit teachers to rightly understand students' attitudes towards the EST course, and they will accordingly teach their learners what is necessary and useful to them about English for Science and Technology.

\section{References :}

Bojovic, M. (2006). Teaching foreign languages for specific purposes: Teacher development.

The proceedings of the $31^{\text {st }}$ Annual Association of Teacher Education in Europe.(pp. 487-493). Retrieved October 30, 2008 from http://www.pef.uni-lj.si/atee/978-961-6637-06-0/487-493.pdf

Dudley-Evans, T., and St. John, M. J. (1998). Developments in English for Specific Purposes: 
Press.

A Multi-disciplinary Approach. Cambridge, Cambridge University

Flowerdew, J. (1990). 'English for specific purposes: A selective review of the literature'. In

ELT Journal, 44/4, 326-337.

Gao, J. (2007). Designing an ESP course for Chinese university students of business. Asian

ESP Journal. 3(1). Retrieved March 20, 2009 from http://www.asianesp-

$$
\text { journal.com/April_2007_gj.php }
$$

Hutchinson, T., and Waters, A. (1987). English for Specific Purposes: A Learner-centered

Approach. Cambridge University Press.

Iwai, T., Kondo, K., Limm, S. J. D., Ray, E. G., Shimizu, H., and Brown, J. D. (1999).

Japanese Language Needs Analysis. Available at:

http://www.nflrc.hawaii.edu/Networks/NW13/NW13.pdf

Jordan, R .R. (1997). English for Academic Purposes: A Guide and Resource Bookfor

Teachers. Cambridge: Cambridge University Press.

Kennedy, C. and R. Bolitho (1984). English for specific purposes. London: Macmillan.

McDonough, J. (1984). ESP in Perspective: A Practical Guide. London: Collins ELT.

Robinson, P.C. (1991). ESP Today: A Practitioner's Guide. New York:

Prentice Hall International.

Trimble, L. (1985). English for Science and Technology: A Discourse Approach.

Cambridge:Cambridge University Press.

Widdowson, H.G. (1979). Explorations in Applied Linguistics. London University Press.

Wilkins. A.D (1976).Notional Syllabus. OUP. 